\title{
Can Powerful Boards Increase Firm Innovativeness When Faced with Exploitative CEOs?
}

\author{
Saleh M. Bajaba ${ }^{1}$, Abdulah M. Bajaba $^{2}$ \& Abdulrahman S. Basahal ${ }^{1}$ \\ ${ }^{1}$ Faculty of Economics and Administration, King Abdul Aziz University, Saudi Arabia \\ ${ }^{2}$ College of Business, Louisiana Tech University, United States \\ Correspondence: Saleh M. Bajaba, Faculty of Economics and Administration, King Abdul Aziz University, P.O. \\ 80201 Jeddah 21589, Saudi Arabia. E-mail: sbajaba@kau.edu.sa
}

Received: September 4, 2020

doi:10.5539/ijbm.v15n11p171
Accepted: October 12, 2020

Online Published: October 21, 2020

URL: https://doi.org/10.5539/ijbm.v15n11p171

\begin{abstract}
Although quite amount of research investigated the detrimental effects of destructive leadership styles at the individual level, less has focused on its effect on the organization as a whole. Therefore, this conceptual paper proposes a model of integration between the micro and the macro level of the organization through investigating the impact of CEO exploitative leadership style on firm innovativeness. Exploitative leadership emphasizes the leader's self-interest through overdelegation of tasks and underchallenging of followers. We propose that CEO exploitative leadership is going to have a detrimental effect on firm innovativeness through TMT behavioral integration as it causes a climate of unfair exchange and hostility, which limits the amount of information being exchanged, collaboration, and joint decision making. We also propose that TMT behavioral integration is an important factor in achieving firm innovativeness, especially when TMT diversity is high. Lastly, board power is proposed to act as an intervention that mitigates the detrimental impact of CEO exploitative leadership on TMT behavioral integration and, ultimately, firm innovativeness, as a powerful board limits/controls any CEO behavior that contradicts the profit-maximizing expectations of the shareholders. Practical implications, limitations, and future directions are also discussed.
\end{abstract}

Keywords: board power, exploitative leadership, firm innovativeness, TMT behavioral integration, TMT diversity

\section{Introduction}

Individual differences between CEOs tend to influence how they react, filter, and attend to information, which consequently influences their construed reality and motivation (Ahmad, 2010; Finkelstein \& Hambrick, 1996; Hambrick \& Mason, 1984; Harrison, Thurgood, Boivie, \& Pfarrer, 2020). The resulting construed reality of the CEOs, then, influences their strategic choice, executive behaviors, and, ultimately, the technological innovativeness and performance of the organization as a whole (Finkelstein \& Hambrick, 1996; Gupta, Nadkarni, \& Mariam, 2019; Hambrick \& Mason, 1984; Kitchell, 1997; Saeed, \& Ziaulhaq, 2019). These individual differences include not only values, beliefs, and attitudes about a subject but also include other psychological factors, such as personality traits (Harrison, Thurgood, Boivie, \& Pfarrer, 2019; O'Reilly III, Caldwell, Chatman, \& Doerr, 2014). An individual's personality is defined as "an individual's relatively permanent, ingrained disposition" (Finkelstein, Hambrick, \& Cannella, 2009). Examples of such personality traits include proactive, narcissistic, abusive, etc. (Chatterjee \& Pollock, 2017; Guo, Katila, Maggitti, \& Tesluk, 2017). These sets of personality traits may influence the executives' tendencies to behave in a certain manner. For example, leadership style is one of the different resulting behaviors of having a specific set of personality traits as a study by Judge, Bono, Ilies, \& Gerhardt (2002) found that the big five personality traits (openness, conscientiousness, extraversion, agreeableness, and neuroticism) significantly relate to the leadership style of the leader, supporting the leader-trait perspective. Consequently, CEO leadership style/behavior can have an effect on numerous organizational outcomes, such as absorptive capacity and firm performance (Eisenbeiss, Van Knippenberg, \& Fahrbach, 2015; Ismail et al., 2009; Hartnell, Kinicki, Lambert, Fugate, \& Corner, 2016; Nikoi, 2009; Rezaei Zadeh, Haak - Saheem, Darwish, Singh, 2020; Wang, Tsui, \& Xin, 2011). Previous studies have explored the effect of positive leadership forms (e.g., transformational leadership) on firm innovativeness (De Tienne, \& Mallette, 2012; Jung, Wu, \& Chow, 2008), but relatively few studies have explored the effect of the negative 
leadership forms on firm innovativeness. As a result, CEO exploitative leadership will be our focal variable of interest; its effect on firm innovativeness will be proposed as it is an important organizational outcome that impacts firm performance (Dibrell, Craig, \& Neubaum, 2014; Srinivasan \& Hanssens, 2009; Tellis, Prabhu, \& Chandy, 2009).

An exploitative leader is "essentially self-interested and treats followers as a means to self-serving ends" (Schmid, Pircher, Verdorfer, \& Peus, 2019). Exploitative leaders tend to 1) attribute the efforts of their followers to themselves in order to privately benefit; 2) influence the followers to follow their self-interested goals; 3 ) overdelegate tasks; and 4) underchallenge the followers by giving them tasks that are tedious or hinder their career (Schmid et al., 2019). Exploitative leaders tend to be narcissistic, individualistic, have self-enhancement goals, and have a personalized power motivation (Williams, 2014). This type of destructive leadership can be detrimental to not only the followers but, ultimately, the organization as a whole. A study by Schmid et al. (2019) investigated some of these detrimental effects on the followers and found that exploitative leadership leads to decreased affective commitment and job satisfaction and increased workplace deviance and burnout. Although quite amount of research investigated the detrimental effects of destructive leadership styles on followers (Krasikova, Green, \& LeBreton, 2013), less has focused on its effect on the organization as a whole, with the majority focusing on the effect of the positive forms of leadership (Carmeli, Schaubroeck, \& Tishler, 2011; Prasad \& Junni, 2016). Therefore, we aim in this study to investigate such effects by including a multi-level perspective in which micro and macro levels of analysis are taken into account. This research is answering Araujo-Cabrera, Suarez-Acosta, \& Aguiar-Quintana (2017)'s call for research regarding examining other frameworks of personality traits that affect the dynamics of Top Management Team (TMT) and organizational outcomes; however, instead of measuring the direct effects of the personality traits, the resulting behavior of such traits (exploitative leadership style) will be the focal variable. Furthermore, this paper expands on the social-interactionism perspective (Bromiley \& Rau, 2016; Carmeli et al., 2011; Georgakakis, Heyden, Oehmichen, \& Ekanayake, 2019), which states that the CEO-TMT interaction is socially construed and based on the behaviors, leadership styles, and psychological attributes of the executives, by emphasizing the resulting TMT processes as an explanatory mechanism in explaining the effect of the CEOs' leadership style on firm outcomes.

We will be proposing the nature of the relationship between CEO exploitative leadership style and firm innovativeness through TMT behavioral integration acting as a mediator. Moreover, we will be proposing the moderating effects of board power on the relationship between CEO exploitative leadership style and TMT behavioral integration along with the moderating effects of TMT diversity on the relationship between TMT behavioral integration and firm innovativeness. Lastly, we will propose a dual-stage moderated mediation model (Muller, Judd, \& Yzerbyt, 2005; Hayes, 2018) involving CEO exploitative leadership (independent variable), board power (moderator), TMT behavioral integration (mediator), TMT diversity (moderator), and firm innovativeness (dependent variable).

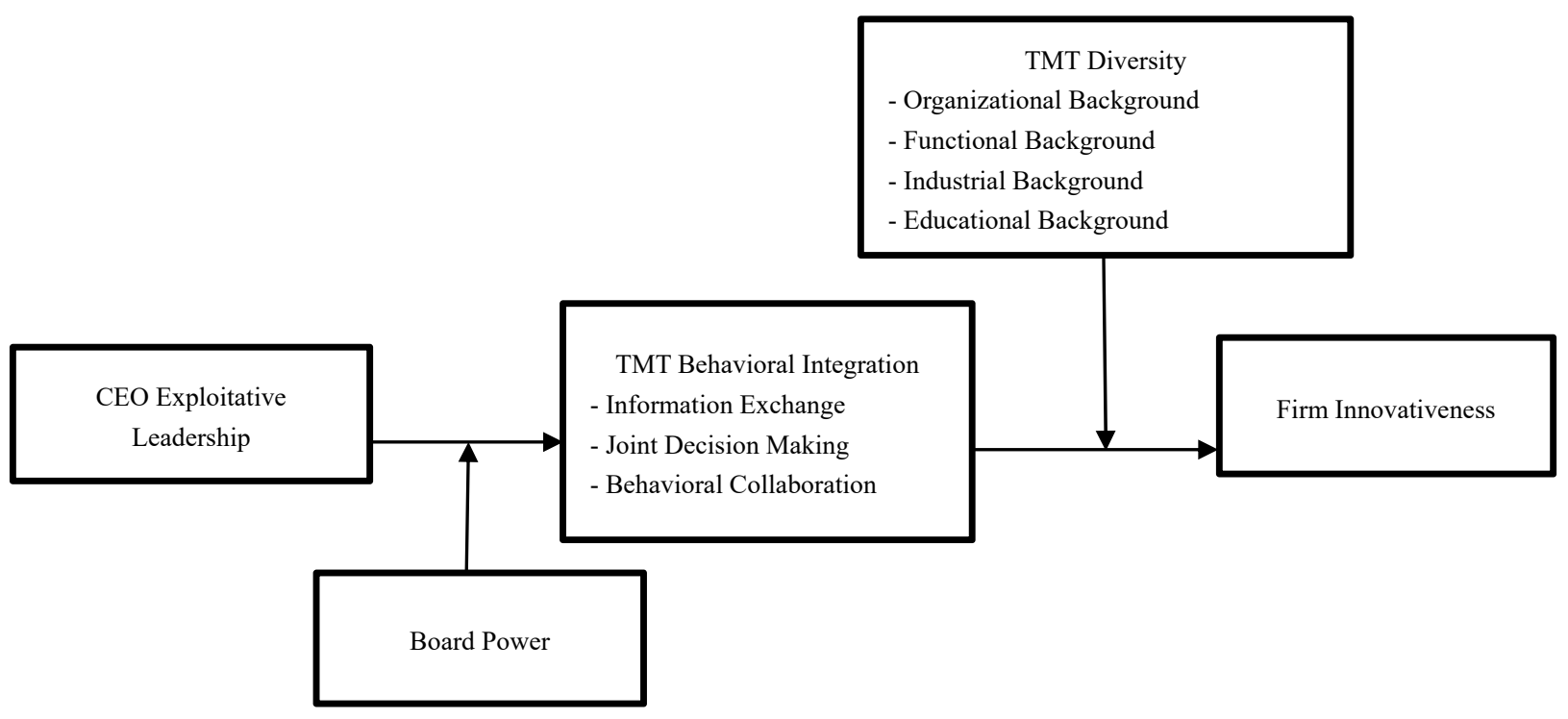

Figure 1. Proposed model 


\section{Literature Review}

\subsection{The Dark Side of CEO Exploitative Leadership}

Exploitative leadership is a newly developed construct by Schmid et al. (2019) through which the leader tries to take credit for all the work done by the follower regardless of how stressful, tedious, or demanding the task of the follower is, which leads to follower's increased levels work deviance and burnout as well as decreased levels of organizational commitment and job satisfaction. This is due to the follower's perception of unfairness towards $\mathrm{him} / \mathrm{her}$ and the overriding of emotional demands necessary to cope with the situation (Schmid et al., 2019). There are multiple theories that rationalize such a phenomenon: conservation of resources and job demands-resources to name a few (Bakker \& Demerouti, 2007; Bakker \& Demerouti, 2014, 2017; Demerouti, Bakker, Nachreiner, \& Schaufeli, 2001; Hobfoll, Halbesleben, Neveu, \& Westman, 2018; Hobfoll \& Shirom, 2001). Conservation of resources theory states that "individuals are motivated to protect their current resources (conservation) and acquire new resources (acquisition)" (Halbesleben, Neveu, Paustian-Underdahl, \& Westman, 2014). These resources can be material resources (e.g., tools for work), personal resources (e.g., personality traits, skills), condition resources (e.g., employment), or energy resources (e.g., money, knowledge; Hobfoll et al., 2018: 105). Two main principles of the theory are the primacy of resource loss principle (individuals are negatively more impacted when they lose a resource than when they gain one) and resource investment principle (individuals store and invest resources to cope with the stressful situation when needed). Based on these principles, an exploitative leader is more likely to exploit all of the follower's resources resulting in resource loss for the follower and draining of its resource investment leading to negative consequences such as strain in the form of burnout (Shirom, 1989).

This conclusion can be further rationalized by the job demands-resources theory, which states that individuals working at an organization have both job demands (e.g., high work pressure, emotionally demanding social interactions with clients, etc.) that can lead to decreased well-being, and job/psychological resources (e.g., autonomy, time, emotional stamina, etc.) that can counteract the effects of job demands leading to increased well-being (Bakker \& Demerouti, 2014, 2017). For example, abusive supervision, defined by Tepper (2000: 178) as "subordinates perceptions of the extent to which their supervisors engage in the sustained display of hostile verbal and nonverbal behaviors, excluding physical contact," has been associated with decreased job satisfaction and performance as well as increased job tension and emotional exhaustion (Mackey, Frieder, Brees, \& Martinko, 2017). In the same manner, exploitative leaders tend to exert more job demands on the follower while draining their job resources leading to decreased commitment and increased burnout (Hakanen, Bakker, \& Schaufeli, 2006). Furthermore, Schmid et al. (2019) have investigated the destructive effects of exploitative leadership and found that there is a significant, positive linear relationship between exploitative leadership behavior and organization-directed destructive leader behavior; one possible organization-directed destructive behavior can be reflected in the limited pursue of firm innovativeness.

Firm innovativeness is defined as "a firm's tendency to engage in and support new ideas, novelty, experimentation, and creative processes that may result in new products, services, or technological processes" (Lampkin \& Dess, 1996: 142). Firm innovativeness is considered to be an important organizational outcome as it provides the organization with a competitive advantage against its competitors (Dougherty \& Hardy, 1996), which can result in increased firm performance (Srinivasan \& Hanssens, 2009; Tellis et al., 2009). One of the main determinants of firm innovativeness is the capacity of exchanging and sharing different perspectives and sources of information as doing so enhances a firm's ability to generate alternatives, evaluate alternatives, and better predict environmental changes (Cannella, Park, \& Lee, 2008). As a result, topics involving absorptive capacity, knowledge sharing processes, and knowledge sources have been of interest (Ganter \& Hecker, 2013; Lin, 2007; Zou, Ertug, \& George, 2018). Therefore, any factor hindering such flow of information is more likely to negatively impact the ability of a firm to innovate.

Accordingly, we expect CEOs who are exploitative to have a negative impact on firm innovativeness due to multiple factors. First, their exploitative nature tends to create a hostile environment of unfairness and oppression, which is more likely to reduce the resources of those working in the organization rendering them less likely to come up with creative/innovative ideas to implement as they will be more focused on reserving their current resources rather than generating new ones (innovation; Hobfoll et al., 2018). Second, agency theory states that agents (managers) will act in their best interest if their goals contradict with the principal's (shareholder's) goals (Eisenhardt, 1989; Ross, 1973). Consequently, an exploitative CEO whose interest is benefitting themselves regardless of all the stakeholders they are working with/for is more likely to prioritize their benefit and not that of the organization or those who work in it. Accordingly, an exploitative CEO is more likely to be risk-averse due to the uncertainty and information asymmetry associated with taking risks, resulting in limited investment in firm innovativeness (Jia, Huang, \& Zhang, 2019). Furthermore, the employees of the organization will be less 
motivated/willing to share their ideas and knowledge given the unfair treatment (Franke, Keinz, \& Klausberger, 2013). Thus, we propose the following:

\section{Proposition 1. CEO exploitative leadership is negatively related to firm innovativeness.}

Although the effect of CEO exploitive leadership is proposed to predict more distal organizational outcomes such as firm innovativeness, its effect can be first noticed on more proximal outcomes, such as TMT behavioral integration. The TMT of any organization consists of the Chief Executive Officer (CEO) of the organization and senior executives such as the Chief Financial Officer (CFO), the Chief Operational Officer (COO), etc. TMT members are "individuals who play a key role in the strategic and practical orientation of the firm" (Carmeli \& Halevi, 2009; Castanias \& Helfat, 1991; Hambrick \& Mason, 1984). TMT behavioral integration is defined as "the degree to which mutual and collective interaction exists within the group" (Hambrick, 1994: 188). It consists of three interdependent processes: behavioral collaboration, information change, and joint decision making. Behavioral collaboration refers to the cooperative behavior of sharing experience and expertise between each of the TMT members; informational exchange refers to the sharing of information between the each of the TMT members; and lastly, joint decision making refers to the extent to which TMT members often reach consensus in major decisions (Hambrick, 1994). Accordingly, a TMT with low behavioral integration is reflected by a lack of behavioral collaboration, lack of information sharing, and no consensus in major decisions, which can lead to detrimental effects on the organization. In other words, TMT behavioral integration is considered to be a pivotal part of any organization's success as it is considered to be the leading force of the establishment. That being said, CEOs can have a drastic impact on TMT behavioral integration because they can "evaluate, reward, motivate, and coach TMT members, as well as facilitate their interactions" (Simsek, Veiga, Lubatkin, \& Dino, 2005: 71). Therefore, a CEO who has an exploitative leadership style may affect its TMT behavioral integration as it might drain its members' resources through creating a hostile environment and overwhelming them with tedious job demands causing the TMT to have low behavioral integration. Furthermore, an exploitative CEO is more likely to pursue goals that fulfill his/her needs instead of the organization or the stakeholders, resulting in less behavioral integration from the other TMT members. This can be rationalized by the social exchange theory which states that social relationships and exchange of value is sustained when it is based on fairness of exchange; otherwise, the social relationship is going to be weakened resulting in a retreat from the oppressed side, the TMT in this case (Blau, 1964; Molm, 2010).

Numerous studies have looked at the effects of CEO on TMT. For example, Lin \& Rababah (2014) studied the effects of CEO-TMT exchange on TMT psychological empowerment and decision quality. The findings indicate that high levels of CEO-TMT exchange, characterized by increased reciprocity quality along with increased emotional and social exchange quality, will lead to increased TMT psychological empowerment, which leads to increased decision quality (Lin \& Rababah, 2014). Other lines of research investigated the dark side of CEO effect on TMT, such as O'Boyle, Forsyth, Banks, \& McDaniel (2012). They investigated how the dark triad violates the norms of social exchange and, thus, result in undermined performance and counterproductive workplace behavior due to the lack of social relationships, which are vital when it comes to job-related outcomes. Similarly, we suggest that TMT members are more likely to feel the unfairness in the social exchange of value working with the exploitative CEO due to self-interested goals and resource depletion caused by overwhelming job demands, which lead them to be more conservative resulting in reduced exchange of information, collaborative behavior, and joint decision making. Building on this reasoning, we propose the following:

Proposition 2. CEO exploitative leadership is negatively related to TMT behavioral integration.

\subsection{The Mediating Role of TMT Behavioral Integration}

Building upon the upper echelon theory, which states that organizational outcomes are mostly influenced by its executives' cognitions, values, perceptions, and strategic choices, we expect TMT behavioral integration to have an effect on firm innovativeness (Bromiley \& Rau, 2016; Hambrick, 2007; Hambrick \& Mason, 1984; Reina, Zhang, \& Peterson, 2014; Smith, Smith, Olian, Sims, O’Bannon, \& Scully, 1994). A TMT that is behaviorally integrated is characterized by "open and timely information exchanges among team members. Such information exchanges allow individual team members to gain access to valuable information, knowledge and complementary skills" (Hambrick, 2007; Luo, Zheng, Ji, \& Liang, 2016: 343). Furthermore, such a high degree of behavioral integration is also characterized by more collaborative behavior and emphasis on joint decision making (Lubatkin, Simsek, Ling, \& Veiga, 2006). Based on such team qualities, TMT members are more likely to share their experiences, knowledge, and skills allowing them to tackle environmental demands from different angles and come up with creative ideas and innovations that otherwise would have been unrecognized without behavioral integration; as a result, members of such team are more than likely to adjust to novel, complex, and 
dynamic situations especially when the nature of the task is uncertain or interdependent (Luo et al., 2016). Therefore, we propose the following:

\section{Proposition 3. TMT behavioral integration is positively related to firm innovativeness.}

Although TMT behavioral integration is expected to be positively related to firm innovativeness, having a CEO who is exploitative is more than likely going to negatively affect this relationship. As discussed before, we expect CEO exploitative leadership to be negatively related to firm innovativeness as they 1) deplete the resources of those working in the organization through overwhelming demands and unfair social exchange and 2) prioritization of self-interest. One proposed explanatory mechanism of such negative impact can be reflected in the reduced TMT behavioral integration as a result of working with such exploitative CEOs. As proposed above, we expect the CEO's exploitative leadership style to be negatively related to TMT behavioral integration due to the created hostile, unfair environment resulting in a team that lacks joint decisions, information sharing, and collaborative behavior. Furthermore, based on the upper echelon theory, the senior executives' perceptions and choices have a significant effect on the organization as a whole (Hambrick, 2007; Hambrick \& Mason, 1984; Harrison, Thurgood, Boivie, \& Pfarrer, 2020; Smith et al., 1994) and, consequently, having a TMT that lacks behavioral integration will negatively impact the capacity of the firm to innovate due to the lack of shared information and collaboration. Thus, we propose the following:

Proposition 4. TMT behavioral integration mediates the relationship between CEO exploitative leadership and firm innovativeness.

\subsection{TMT Diversity as an Enhancer}

Further building upon the upper echelon theory, TMT diversity - the extent to which the executives differ on multiple levels including industrial background, educational background, functional background, and organizational background - will certainly have an impact on the firm's strategic choice and outcomes, especially innovativeness (Hambrick \& Mason, 1984; Harrison, Thurgood, Boivie, \& Pfarrer, 2020). There are numerous reasons for this rationalization as TMT diversity, also known as TMT heterogeneity, deals with the disadvantage of "bounded rationality" by creating teams that are cognitively diverse in order to cover more perspectives, and thus, make better, more innovative and strategic decisions. For example, TMT functional diversity tends to provide the team with a broader range of managerial and technical skills, which leads to information variety that leads to innovativeness (Cannella et al., 2008; Guo, Pang, \& Li, 2018; Milliken \& Martins, 1996; Simons, Pelled, \& Smith, 1999). Researchers such as Bunderson \& Sutcliffe (2002) and Dahlin, Weingart, \& Hinds (2005) investigated such effects and found that functional diversity leads to increased information sharing and use. Similarly, educational diversity leads to increased knowledge sharing which leads to better opportunity recognition, and consequently, innovation (Cohen \& Levinthal, 1990; Smith et al., 1994).

In addition to information and knowledge sharing, TMT diversity has been found to be related to other factors that also increases firm innovativeness. For instance, industrial diversity was found to increase extra-industry ties - leading to more deviation from the industry norms - which results in a strategic choice/decision that focuses on the customers' needs by scouting for new ideas and solutions (Geletkanycz \& Hambrick, 1997). Furthermore, although TMT diversity can lead to conflicts and disagreement resulting in reduced consensus, especially in complex and uncertain situations (Bantel \& Jackson, 1989), it increases the motivation to debate and challenge the status quo (Michel \& Hambrick, 1992). This should produce a much greater variation in decision making due to the fact that it will challenge the ideas of the executives requiring them to rethink their strategy to improve it by discussing alternatives and considering new factors (Talke, Salomo, \& Kock, 2011). Based on such arguments, we suggest that TMT diversity should act as a moderator between TMT behavioral integration and firm innovativeness such that the effect of information sharing, consensus, and joint decision making on firm innovativeness is enhanced by the uniqueness of the information being shared and discussed. Therefore, we propose the following:

Proposition 5. TMT diversity moderates the relationship between TMT behavioral integration and firm innovativeness such that higher levels of TMT diversity strengthen the relationship.

\subsection{The Role of Board Power}

Board power refers to the board's effectiveness and capability in monitoring and exerting influence on the TMT in the organization, especially the CEO (Finkelstein et al., 2009; Payne, Benson, \& Finegold, 2009). The board of directors is mostly founded as a solution to the agency problem stated by the agency theory: managers might act in their best interest if their goals do not match those of the shareholders. One of the board's most important functions is monitoring the performance and choice implementation of the organization's executive managers in order to 
make sure that the shareholder's expectations are being met (Boivie, Bednar, Aguilera, \& Andrus, 2016). Hillman \& Dalziel, 2003). In other words, "the managers initiate and implement their decisions, while the board members ratify them and, in general, monitor the conduct of the firm's top managers" (Fama \& Jensen, 1983a, 1983b). Assuming that the environment is not constraining (e.g., has significant barriers to entry that are hard to bring down), there are numerous managerial factors through which the board of directors can assess the situation/performance of the managers, such as ability and effort (Walsh \& Seward 1990; Weiner, Frieze, Kukla, Reed, Rest, \& Rosenbaum, 1972). Based on the ability and effort of the manager, the board of directors can assess the situation and, thus, follow the necessary steps in solving the problem. For example, if the board notices that the CEO possesses a high ability in managing the organization but shows low efforts, then the board might alter their incentive plan in order to motivate them. However, if the CEO shows low ability and low efforts, then an incentive plan alteration is not enough to increase performance, which will lead the board to release the CEO of their duties as improving the current CEO's ability costs much more resources than hiring a new, capable one (Walsh \& Seward 1990).

Board power does not only encompass the explicit exercise of power to influence the TMT but also the implicit one (Brass \& Burkhardt, 1993; Pfeffer, 1992; Ranson, Hinings, \& Greenwood, 1980; Wrong 1968); In other words, a powerful board can exert influence on the TMT even "outside the board room" (Forbes \& Milliken, 1999: 494). Therefore, having a powerful board that can take action against unsound decisions or decisions that do not share the interest of the shareholders is certainly going to self-discipline the TMT, especially the CEO, as their job security might be jeopardized (McNulty \& Pettigrew, 1999). This is also applicable when the CEO has high dominance over the rest of the TMT members, which is the discussion of interest in this paper. For example, if the CEO advances a deviant strategy that the rest of the TMT significantly disagree with, the board of directors can reject such a proposal if it is unsound (Hayward \& Hambrick, 1997; Ranft \& O'Neill, 2001). Tang, Crossan, and Rowe (2011) investigated the moderating effects of board power on CEO dominance, strategic deviance, firm extremeness, and firm performance; their findings suggest that the higher the board power is, the more negative the relationship between CEO dominance and firm extremeness becomes and vice versa; on the other hand, the higher the board power, the more positive the relationship between CEO dominance and firm performance becomes and vice versa (Tang et al., 2011). In other words, these results suggest powerful boards have a strong effect on what a dominant CEO can do and, thus, become essential in cases where CEOs are dominant, which is relevant to our focal variable in this paper: CEO exploitative leadership. Therefore, we expect that board power is going to moderate the relationship between CEO exploitative leadership and TMT behavioral integration due to the fact that exploitative CEOs are more than likely to deviate from the shareholder's interests along with creating an environment of disagreement and hostility for the TMT; that being said, a powerful board is more than likely going to address the dilemma through taking action to redirect the exploitative CEOs interests/efforts or release them, thus, jeopardizing the CEOs position in the organization. Consequently, this is expected to lead to decreased exploitative leadership behavior from the CEO, which will result in a more behaviorally integrated TMT. Thus, we propose the following:

Proposition 6. Board power moderates the relationship between CEO exploitative leadership and TMT behavioral integration such that high levels of board power result in higher levels of TMT behavioral integration; low levels of board power results in lower levels of TMT behavioral integration.

Furthermore, we propose a moderated mediation model that explains the indirect effect of CEO exploitative leadership on firm innovativeness via TMT behavioral integration when moderated by board power (Edwards \& Lambert, 2007). Following the same logic as the previous hypothesis, we expect that when board power is high, the effect of CEO exploitative leadership on TMT behavioral integration is going to be less negative due to the monitoring and disciplining by the board resulting in a fairer and less hostile environment. Consequently, a TMT that is more behaviorally integrated is more likely to increase firm innovativeness as the TMT is more likely going to exchange information, make joint decisions, and collaborate more. These effects should be enhanced when board members are independent, motivated, and have high bandwidth and expertise, as this will increase their monitoring effectiveness and strategic perspective on the decisions made by the TMT (Hambrick, Misangyi, \& Park, 2015; Pfeffer \& Salancik, 1978; Walters, Kroll, \& Wright, 2007). Thus, we propose the following moderated mediation model:

Proposition 7. The indirect effect of CEO exploitative leadership on firm innovativeness via TMT behavioral integration is moderated by board power such that the indirect effect is less negative at higher levels of board power and more negative at lower levels of board power.

Building upon proposition 7, we propose that the moderating effect of board power might capitalize on the otherwise untapped potential of having a diverse TMT, thereby further reducing the negative effect of CEO 
exploitative leadership on firm innovativeness. Because CEO exploitative leadership is proposed to reduce TMT behavioral integration, and thus, not encouraging sharing of information, joint decision making, and behavioral collaboration, the benefits of having a TMT with diverse experiences and perspectives are not likely to be realized. That being said, a powerful board is more likely to reduce such negative effect by allowing for more behaviorally integrated TMTs and, thus, sharing of unique perspectives and skills in the case of diverse TMTs, resulting in increased firm innovativeness. Therefore, we propose the following dual-stage moderated mediation model:

Proposition 8. The indirect effect of CEO exploitative leadership on firm innovativeness via TMT behavioral integration is moderated by board power and TMT diversity such that the indirect effect is least negative at high levels of board power and TMT diversity.

\section{Discussion}

This conceptual paper offers insight into the detrimental effects that a CEO is capable of achieving based on his/her leadership style. Although the CEO is only an individual in a firm, s/he still possesses a lot of power through which $\mathrm{s} / \mathrm{he}$ can drastically alter the organizational outcomes. We propose that having a CEO who is exploitative is more likely going to negatively affect the organization as they prioritize their own benefit over that of the organization. This has also been conceptualized/supported by the agency theory (Eisenhardt, 1989), which is considered a major problem for the stakeholders who depend on the firm and have invested in it. Thus, firm innovativeness was the focal organizational outcome of this paper as the exploitative CEO is not likely to encourage the organization to take risks or explore, especially if it might induce losses to him/herself because they are not willing to sacrifice for organizational success or benefiting the stakeholder. One of the mechanisms proposed to explain such a relationship is TMT behavioral integration. An exploitative CEO will mostly utilize methods or outcomes that guarantees their benefit even if it means manipulating, underchallenging, or exploiting the other TMT members. We propose that this would create a hostile, unfair environment based on the social exchange theory (Blau, 1964), and thus, lead to a hostile environment of limited collaboration, joint decision making, and exchange of information. Past research has demonstrated the importance of discussion and sharing of ideas for innovation (Luo et al., 2016); therefore, we propose that a TMT that does not have this kind of social environment is expected to reduce firm innovativeness as they are considered to be the ones pulling levers of the organization.

Moreover, this paper proposes that there are beneficial outcomes to having a TMT that is diverse (based on the industry, organization, education, or function). The argument for the proposed relationship is that having diverse skills, experiences, and knowledge sources is expected to increase debating and sharing of diverse ideas resulting in increased firm innovativeness. In other words, it acts as an advantage of creative thinking. Lastly, this paper suggests a mean through which the negative effects of exploitative CEOs can be hindered or eliminated by implementing a powerful board of directors. One of the responsibilities of such a team is to monitor the behaviors of the TMT members, especially the CEO, to ensure that the stakeholders' goals are met. Therefore, this paper proposes that implementing a powerful board will constrict the exploitative behaviors of the CEOs through warnings, or sometimes firing, which will lead to a less hostile environment for the TMT. Consequently, having a less hostile environment is proposed to increase the behavioral integration of the TMT leading to increased firm innovativeness, especially for firms with diverse TMTs.

This work has multiple theoretical contributions. First, it contributes to the social-interactionism perspective (Bromiley \& Rau, 2016; Georgakakis et al., 2019) by emphasizing the role that CEOs play in influencing the dynamics of the TMT from a negative perspective rather than a positive one as in previous studies (Carmeli et al., 2011; Prasad \& Junni, 2016). Second, it explores a new form of destructive leadership, exploitative leadership, and proposes its hindering effect at the organizational level (Schmid et al., 2019). Third, it expands on the remedies to the agency problem by highlighting board power as an important solution to monitor the detrimental effect of exploitative CEOs on the innovative potential of a firm, especially when its TMT is of diverse properties (Panda \& Leepsa, 2017). In sum, this paper demonstrates how the behaviors of the CEO can alter an organizational outcome through indirectly influencing the behaviors of the other TMT members, and how powerful boards can combat such an effect to uncover otherwise untapped potential.

\subsection{Practical Implications}

The practical implications of this paper include finding ways to limit the negative influences/effects of CEOs, in this case, exploitative leadership. According to Quigley and Hambrick (2015), the influence of CEOs on organizational outcomes has been increasing considerably over the period 1950-2009. This indicates the importance of optimizing the CEO effect on organizational outcomes, and thus, this paper suggests hiring a 
powerful board of directors to monitor the behaviors of the TMT members, especially the CEO, in order to ensure meeting the stakeholder's goals. This implication is most important in firms with diverse TMTs due to the missed opportunities associated with not utilizing the diverse perspectives and experiences of the TMT members. Furthermore, we suggest implementing training sessions for TMT members every now and then that train them on how to be more behaviorally integrated, as we propose that it highly relates to firm innovativeness and the success of the organization.

\subsection{Limitations and Future Directions}

This conceptual paper has some limitations and future research should address them. First, the proposed model implies that CEO exploitative leadership will have an effect on TMT behavioral integration and firm innovativeness; however, it would be hard to assess the TMT members', other than the CEO, perceptions of the CEO's exploitative leadership style through surveys or questionnaires (e.g., Schmid et al., 2019) as it can be hard to reach them and/or they might not be willing to answer such questions due to job security reasons. Therefore, future research should find a more accessible way to measure CEO exploitative leadership style (e.g., qualitative interviews, text analysis). Furthermore, even if the CEO is reached, will s/he be open to discussing such a behavior or admitting to it? That being said, future research should try to measure such leadership style in a way that eliminates any social desirability effects that result from the questions or the items of the survey (Podsakoff, MacKenzie, Lee, \& Podsakoff, 2003).

Future research should investigate other methods of controlling the negative effects of CEOs other than hiring a powerful board, as this is not always plausible. This is because the CEO can have duality (be a member of the board alongside managing the organization) which can eliminate the possibility of having a powerful board. Moreover, future research should investigate other mechanisms through which CEO exploitative leadership style functions can affect not only firm innovativeness but other organizational outcomes as well, such as firm performance and extremeness. Lastly, future research should investigate industry as a plausible moderator such that industries that need high levels of innovation (e.g., technology sector) might lead to increased firm innovativeness whereas industries that do not require high levels of innovation (e.g., construction sector) might render the relationship between TMT behavioral integration and firm innovativeness insignificant.

\section{Conclusion}

This conceptual paper proposes a model for the relationship between CEO exploitative leadership style and firm innovativeness through TMT behavioral integration. CEO exploitative leadership is proposed to create a hostile environment for the TMT as s/he prioritizes their benefit over that of others leading to less communication, collaboration, and joint decision making among the members; this, in turn, is proposed to decrease firm innovativeness. It is also proposed that TMT diversity strengthens the relationship between TMT behavioral integration and firm innovativeness due to the variety of perspectives involved. Lastly, board power is proposed to restrict the negative direct effects of CEO exploitative leadership on TMT behavioral integration and the negative indirect relationship of CEO exploitative leadership on firm innovativeness through TMT behavioral integration, especially when TMT diversity is high.

\section{References}

Ahmad, H. M. (2010). Personality traits among entrepreneurial and professional CEOs in SMEs. International Journal of Business and Management, 5(9), 203. do:10.5539/ijbm.v5n9p203

Araujo-Cabrera, Y., Suarez-Acosta, M. A., \& Aguiar-Quintana, T. (2017). Exploring the influence of CEO extraversion and openness to experience on firm performance: The mediating role of top management team behavioral integration. Journal of Leadership \& Organizational Studies, 24(2), 201-215. https://doi.org/10.1177/1548051816655991

Bakker, A. B., \& Demerouti, E. (2007). The job demands-resources model: State of the art. Journal of Managerial Psychology, 22(3), 309-328. https://doi.org/10.1108/02683940710733115

Bakker, A. B., \& Demerouti, E. (2014). Job demands-resources theory. In P. Y. Chen \& C. L. Cooper (Eds.), Wellbeing: A complete reference guide. Work and wellbeing (pp. 37-64). Wiley-Blackwell.

Bakker, A. B., \& Demerouti, E. (2017). Job demands-resources theory: taking stock and looking forward. Journal of Occupational Health Psychology, 22(3), 273-285. http://dx.doi.org/10.1037/ocp0000056

Bantel, K. A., \& Jackson, S. E. (1989). Top management and innovations in banking: Does the composition of the top team make a difference? Strategic Management Journal, 10, 107-124. https://doi.org/10.1002/smj.4250100709 
Blau, P. M. (1964). Exchange and power in social life. Transaction Publishers.

Boivie, S., Bednar, M. K., Aguilera, R. V., \& Andrus, J. L. (2016). Are boards designed to fail? The implausibility of effective board monitoring. Academy of Management Annals, 10(1), 319-407. https://doi.org/10.5465/19416520.2016.1120957

Brass, D. J., \& Burkhardt, M. E. (1993). Potential power and power use: An investigation of structure and behavior. Academy of Management Journal, 36(3), 441-470. https://doi.org/10.5465/256588

Bromiley, P., \& Rau, D. (2016). Social, behavioral, and cognitive influences on upper echelons during strategy process: A literature review. Journal of Management, 42(1), 174-202. https://doi.org/10.1177/0149206315617240

Cannella Jr, A. A., Park, J. H., \& Lee, H. U. (2008). Top management team functional background diversity and firm performance: Examining the roles of team member colocation and environmental uncertainty. Academy of Management Journal, 51(4), 768-784. https://doi.org/10.5465/amr.2008.33665310

Carmeli, A., \& Halevi, M. Y. (2009). How top management team behavioral integration and behavioral complexity enable organizational ambidexterity: The moderating role of contextual ambidexterity. The Leadership Quarterly, 20(2), 207-218. https://doi.org/10.1016/j.leaqua.2009.01.011

Carmeli, A., Schaubroeck, J., \& Tishler, A. (2011). How CEO empowering leadership shapes top management team processes: Implications for firm performance. The Leadership Quarterly, 22, 399-411. https://doi.org/10.1016/j.leaqua.2011.02.013

Castanias, R. P., \& Helfat, C. E. (1991). Managerial resources and rents. Journal of Management, 17(1), $155-171$. https://doi.org/10.1177/014920639101700110

Chatterjee, A., \& Pollock, T. G. (2017). Master of puppets: How narcissistic CEOs construct their professional worlds. Academy of Management Review, 42(4), 703-725. https://doi.org/10.5465/amr.2015.0224

Cohen, W. M., \& Levinthal, D. A. (1990). Absorptive capacity: A new perspective on learning and innovation. Administrative Science Quarterly, 35(1), 128-52. https://doi.org/10.2307/2393553

Dahlin, K. B., Weingart, L. R., \& Hinds, P. J. (2005). Team diversity and information use. Academy of Management Journal, 48(6), 1107-1123. https://doi.org/10.5465/amj.2005.19573112

De Tienne, D., \& Mallette, P. (2012). Antecedents and outcomes of innovation-oriented cultures. International Journal of Business and Management, 7(18), 1. http://dx.doi.org/10.5539/ijbm.v7n18p1

Demerouti, E., Bakker, A. B., Nachreiner, F., \& Schaufeli, W. B. (2001). The job demands-resources model of burnout. Journal of Applied psychology, 86(3), 499-512. https://doi.org/10.1037/0021-9010.86.3.499

Dibrell, C., Craig, J. B., \& Neubaum, D. O. (2014). Linking the formal strategic planning process, planning flexibility, and innovativeness to firm performance. Journal of Business Research, 67(9), 2000-2007. https://doi.org/10.1016/j.jbusres.2013.10.011

Dougherty, D., \& Hardy, C. (1996). Sustained product innovation in large, mature organizations: Overcoming innovation-to-organization problems. Academy of Management Journal, 39(5), 1120-1153. https://doi.org/10.5465/256994

Edwards, J. R., \& Lambert, L. S. (2007). Methods for integrating moderation and mediation: A general analytical framework using moderated path analysis. Psychological Methods, 12(1), 1-22. https://doi.org/10.1037/1082-989X.12.1.1

Eisenbeiss, S. A., Van Knippenberg, D., \& Fahrbach, C. M. (2015). Doing well by doing good? analyzing the relationship between CEO ethical leadership and firm performance. Journal of Business Ethics, 128(3), 635-651. https://doi.org/10.1007/s10551-014-2124-9

Eisenhardt, K. M. (1989). Agency theory: An assessment and review. Academy of Management Review, 14(1), 57-74. https://doi.org/10.5465/amr.1989.4279003

Fama, E. F., \& Jensen, M. C. (1983a). Separation of ownership and control. The journal of law and Economics, 26(2), 301-325.

Fama, E. F., \& Jensen, M. C. (1983b). Agency problems and residual claims. The Journal of Law and Economics, $26(2), 327-349$.

Finkelstein, S., \& Hambrick, D. C. (1996). Strategic leadership: Top executives and their effects on organizations. Australian Journal of Management, 22(2), 221-224. https://doi.org/10.1177/031289629702200205 
Finkelstein, S., Hambrick, D. C., \& Cannella, A. A. (2009). Strategic leadership: Theory and research on executives, top management teams, and boards. New York: Oxford University Press.

Franke, N., Keinz, P., \& Klausberger, K. (2013). "Does this sound like a fair deal?": Antecedents and consequences of fairness expectations in the individual's decision to participate in firm innovation. Organization Science, 24(5), 1495-1516. https://doi.org/10.1287/orsc.1120.0794

Ganter, A., \& Hecker, A. (2013). Deciphering antecedents of organizational innovation. Journal of Business Research, 66(5), 575-584. https://doi.org/10.1016/j.jbusres.2012.02.040

Geletkanycz, M. A., \& Hambrick, D. C. (1997). The external ties of top executives: Implications for strategic choice and performance. Administrative Science Quarterly, 42(4), 654-681. https://doi.org/10.2307/2393653

Georgakakis, D., Heyden, M. L., Oehmichen, J. D., \& Ekanayake, U. I. (2019). Four decades of CEO-TMT interface research: A review inspired by role theory. The Leadership Quarterly, 101-354. https://doi.org/10.1016/j.leaqua.2019.101354

Guo, B., Pang, X., \& Li, W. (2018). The role of top management team diversity in shaping the performance of business model innovation: a threshold effect. Technology Analysis \& Strategic Management, 30(2), $241-253$. https://doi.org/10.1080/09537325.2017.1300250

Guo, W., Katila, R., Maggitti, P. G., \& Tesluk, P. E. (2017). Innovation at the top: Proactive CEO, top executive attention focus, and product innovation. In Academy of Management Proceedings, 2017(1). Briarcliff Manor, NY. https://doi.org/10.5465/AMBPP.2017.14562abstract

Gupta, A., Nadkarni, S., \& Mariam, M. (2019). Dispositional sources of managerial discretion: CEO ideology, CEO personality, and firm strategies. Administrative Science Quarterly, 64(4), 855-893. https://doi.org/10.1177/0001839218793128

Hakanen, J. J., Bakker, A. B., \& Schaufeli, W. B. (2006). Burnout and work engagement among teachers. Journal of School Psychology, 43(6), 495-513. https://doi.org/10.1016/j.jsp.2005.11.001

Halbesleben, J. R., Neveu, J. P., Paustian-Underdahl, S. C., \& Westman, M. (2014). Getting to the "COR" understanding the role of resources in conservation of resources theory. Journal of Management, 40(5), 1334-1364. https://doi.org/10.1177/0149206314527130

Hambrick, D. C. (1994). Top management groups: A conceptual integration and reconsideration of the team label. In B. M. Staw \& L. L. Cummings (Eds.), Research in Organizational Behavior, (Vol. 16, pp. 171-214). Greenwich, CT: JAI.

Hambrick, D. C. (2007). Upper echelons theory: An update. Academy of Management Review, 32(2), 334-343. https://doi.org/10.5465/amr.2007.24345254

Hambrick, D. C., \& Mason, P. A. (1984). Upper echelons: The organization as a reflection of its top managers. Academy of Management Review, 9(2), 193-206.

Hambrick, D. C., Misangyi, V. F., \& Park, C. A. (2015). The quad model for identifying a corporate director's potential for effective monitoring: Toward a new theory of board sufficiency. Academy of Management Review, 40(3), 323-344. https://doi.org/10.5465/amr.2014.0066

Harrison, J. S., Thurgood, G. R., Boivie, S., \& Pfarrer, M. D. (2019). Measuring CEO personality: Developing, validating, and testing a linguistic tool. Strategic Management Journal, 40(8), 1316-1330. https://doi.org/10.1002/smj.3023

Harrison, J. S., Thurgood, G. R., Boivie, S., \& Pfarrer, M. D. (2020). Perception is reality: How ceos' observed personality influences market perceptions of firm risk and shareholder returns. Academy of Management Journal, 63(4), 1166-1195. https://doi.org/10.5465/amj.2018.0626

Hartnell, C. A., Kinicki, A. J., Lambert, L. S., Fugate, M., \& Doyle Corner, P. (2016). Do similarities or differences between CEO leadership and organizational culture have a more positive effect on firm performance? A test of competing predictions. Journal of Applied Psychology, 101(6), 846. http://dx.doi.org/10.1037/apl0000083

Hayes, A. F. (2018). Partial, conditional, and moderated moderated mediation: Quantification, inference, and interpretation. Communication Monographs, 85(1), 4-40. https://doi.org/10.1080/03637751.2017.1352100

Hayward, M. L., \& Hambrick, D. C. (1997). Explaining the premiums paid for large acquisitions: Evidence of 
CEO hubris. Administrative Science Quarterly, 42, 103-127. https://doi.org/10.2307/2393810

Hillman, A. J., \& Dalziel, T. (2003). Boards of directors and firm performance: Integrating agency and resource dependence perspectives. Academy of Management Review, 28(3), 383-396. https://doi.org/10.5465/amr.2003.10196729

Hobfoll, S. E., \& Shirom, A. (2001). Conservation of resources theory: Applications to stress and management in the workplace. In R. T. Golembiewski (Ed.), Handbook of Organizational Behavior, (pp. 57-80). New York, NY, US: Marcel Dekker.

Hobfoll, S. E., Halbesleben, J., Neveu, J. P., \& Westman, M. (2018). Conservation of resources in the organizational context: The reality of resources and their consequences. Annual Review of Organizational $\begin{array}{llll}\text { Psychology and Organizational Behavior, } & \text { 5, }\end{array}$ https://doi.org/10.1146/annurev-orgpsych-032117-104640.

Ismail, A., Halim, F. A., Abdullah, D. N. M. A., Shminan Ahmad, S., Muda, A. L. A., Samsudin, S., \& Girardi, A. (2009). The mediating effect of empowerment in the relationship between transformational leadership and service quality. International Journal of Business and Management, 4(4). https://doi.org/10.5539/ijbm.v4n4p3

Jia, N., Huang, K. G., \& Man Zhang, C. (2019). Public governance, corporate governance, and firm innovation: An examination of state-owned enterprises. Academy of Management Journal, 62(1), 220-247. https://doi.org/10.5465/amj.2016.0543

Judge, T. A., Bono, J. E., Ilies, R., \& Gerhardt, M. W. (2002). Personality and leadership: A qualitative and quantitative review. Journal of Applied Psychology, 87(4), 765-780. https://doi.org/10.1037//0021-9010.87.4.765

Jung, D. D., Wu, A., \& Chow, C. W. (2008). Towards understanding the direct and indirect effects of CEOs' transformational leadership on firm innovation. The Leadership Quarterly, 19(5), 582-594. https://doi.org/10.1016/j.leaqua.2008.07.007

Kitchell, S. (1997). CEO characteristics and technological innovativeness: A Canadian perspective. Canadian Journal of Administrative Sciences/Revue Canadienne des Sciences de l'Administration, 14(2), 111-121. https://doi.org/10.1111/j.1936-4490.1997.tb00123.x

Krasikova, D. V., Green, S. G., \& LeBreton, J. M. (2013). Destructive leadership: A theoretical review, integration, and future research agenda. Journal of Management, 39(5), 1308-1338. https://doi.org/10.1177/0149206312471388

Lin, H. (2007). Knowledge sharing and firm innovation capability: an empirical study. International Journal of Manpower, 28(3/4), 315-332. https://doi.org/10.1108/01437720710755272

Lin, H. C., \& Rababah, N. (2014). CEO-TMT exchange, TMT personality composition, and decision quality: The mediating role of TMT psychological empowerment. The Leadership Quarterly, 25(5), 943-957. https://doi.org/10.1016/j.leaqua.2014.06.005

Lubatkin, M. H., Simsek, Z., Ling, Y., \& Veiga, J. F. (2006). Ambidexterity and performance in small-to medium-sized firms: The pivotal role of top management team behavioral integration. Journal of Management, 32(5), 646-672. https://doi.org/10.1177/0149206306290712

Luo, B., Zheng, S., Ji, H., \& Liang, L. (2016). Ambidextrous leadership and TMT-member ambidextrous behavior: The role of TMT behavioral integration and TMT risk propensity. The International Journal of Human Resource Management, 29(2), 338-359. https://doi.org/10.1080/09585192.2016.1194871

Mackey, J. D., Frieder, R. E., Brees, J. R., \& Martinko, M. J. (2017). Abusive supervision: A meta-analysis and empirical review. Journal of Management, 43(6), 1940-1965. https://doi.org/10.1177/0149206315573997

McNulty, T., \& Pettigrew, A. (1999). Strategists on the board. Organization Studies, 20(1), 47-74. https://doi.org/10.1177/0170840699201003

Michel, J. G., \& Hambrick D. C. (1992). Diversification posture and top management team characteristics. Academy of Management Journal, 35(1), 9-38. https://doi.org/10.5465/256471

Milliken, F. J., \& Martins L. L. (1996). Searching for common threads: Understanding the multiple effects of diversity in organizational groups. Academy of Management Review 21(2), 402-433. https://doi.org/10.5465/amr.1996.9605060217 
Molm, L. D. (2010). The structure of reciprocity. Social Psychology Quarterly, 73(2), 119-131. https://doi.org/10.1177/0190272510369079

Muller, D., Judd, C. M., \& Yzerbyt, V. Y. (2005). When moderation is mediated and mediation is moderated. Journal of Personality and Social Psychology, 89(6), 852-863. https://doi.org/10.1037/0022-3514.89.6.852

Nikoi, A. (2009). Ethical leadership and business decision making in contemporary times. International Journal of Business and Management, 3(10), 183-193. https://doi.org/10.5539/ijbm.v3n10p183

O'Reilly III, C. A., Caldwell, D. F., Chatman, J. A., \& Doerr, B. (2014). The promise and problems of organizational culture: CEO personality, culture, and firm performance. Group \& Organization Management, 39(6), 595-625. https://doi.org/10.1177/1059601114550713

O'Boyle Jr., Ernest H., Forsyth, D. R., Banks, G. C., \& McDaniel, M. A. (2012). A meta-analysis of the dark triad and work behavior: A social exchange perspective. Journal of Applied Psychology, 97(3), 557-579. https://doi.org/10.1037/a0025679

Panda, B., \& Leepsa, N. M. (2017). Agency theory: Review of theory and evidence on problems and perspectives. Indian Journal of Corporate Governance, 10(1), 74-95. https://doi.org/10.1177/0974686217701467

Payne, G. T., Benson, G. S., \& Finegold, D. L. (2009). Corporate board attributes, team effectiveness and financial performance. Journal of Management Studies, 46(4), 704-731. https://doi.org/10.1111/j.1467-6486.2008.00819.x

Pfeffer, J. (1992). Managing with power: Politics and influence in organizations. Boston, MA: Harvard Business School Press.

Pfeffer, J., \& Salancik, G. R. (1978). The external control of organizations: A resource dependence approach. NY: Harper and Row Publishers.

Podsakoff, P. M., MacKenzie, S. B., Lee, J. Y., \& Podsakoff, N. P. (2003). Common method biases in behavioral research: A critical review of the literature and recommended remedies. Journal of Applied Psychology, 88(5), 879-903. https://doi.org/10.1037/0021-9010.88.5.879

Prasad, B., \& Junni, P. (2016). CEO transformational and transactional leadership and organizational innovation: The moderating role of environmental dynamism. Management Decision, 54(7), 1542-1568. https://doi.org/10.1108/MD-11-2014-0651

Quigley, T. J., \& Hambrick, D. C. (2015). Has the "CEO effect" increased in recent decades? A new explanation for the great rise in America's attention to corporate leaders. Strategic Management Journal, 36(6), 821-830. https://doi.org/10.1002/smj.2258

Ranft, A. L., \& O'Neill, H. M. (2001). Board composition and high-flying founders: Hints of trouble to come? The Academy of Management Executive, 15(1), 126-138. https://doi.org/10.5465/ame.2001.4251562

Ranson, S., Hinings, B., \& Greenwood, R. (1980). The structuring of organizational structures. Administrative Science Quarterly, 25(1), 1-17. https://doi.org/10.2307/2392223

Reina, C. S., Zhang, Z., \& Peterson, S. J. (2014). CEO grandiose narcissism and firm performance: The role of organizational identification. The Leadership Quarterly, 25(5), 958-971. https://doi.org/10.1016/j.leaqua.2014.06.004

Rezaei Zadeh, M, Haak - Saheem, W, Darwish, TK, Singh, S. (2020) The Impact of Leadership on Absorptive Capacity: New insights from the UAE. Canadian Journal of Administrative Sciences/Revue Canadienne des Sciences de l'Administration, 1-11. https://doi.org/10.1002/cjas.1561

Ross, S. A. (1973). The economic theory of agency: The principal's problem. The American Economic Review, 63(2), 134-139.

Saeed, A., \& Ziaulhaq, H. M. (2019). The Impact of CEO Characteristics on the Internationalization of SMEs: Evidence from the UK. Canadian Journal of Administrative Sciences/Revue Canadienne des Sciences de l'Administration, 36(3), 322-335. https://doi.org/10.1002/cjas.1497

Schmid, E. A., Pircher Verdorfer, A., \& Peus, C. (2019). Shedding light on leaders' self-interest: theory and measurement of exploitative leadership. Journal of Management, 45(4), 1401-1433. https://doi.org/10.1177/0149206317707810

Shirom, A. (1989). Burnout in work organizations. In C. L. Cooper \& I. T. Robertson (Eds.), International 
review of industrial and organizational psychology (pp. 25-48). Oxford, England: John Wiley \& Sons.

Simons, T., Pelled, L. H., \& Smith, K. A. (1999). Making use of difference: Diversity, debate, and decision comprehensiveness i top management teams. Academy of Management Journal, 42(6), 662-473. https://doi.org/10.5465/256987

Simsek, Z., Veiga, J. F., Lubatkin, M. H., \& Dino, R. N. (2005). Modeling the multilevel determinants of top management team behavioral integration. Academy of Management Journal, 48(1), 69-84. https://doi.org/10.5465/amj.2005.15993139

Smith, K. G., Smith, K. A., Olian, J. D., Sims, H. P., O’Bannon, D. P., \& Scully, J. A. (1994). Top management team demography and process: The role of social integration and communication. Administrative Science Quarterly, 39, 412-438. https://doi.org/10.2307/2393297

Srinivasan, S., \& Hanssens, D. M. (2009). Marketing and firm value: Metrics, methods, findings, and future directions. Journal of Marketing Research, 46(3), 293-312. https://doi.org/10.1509/jmkr.46.3.293

Talke, K., Salomo, S., \& Kock, A. (2011). Top management team diversity and strategic innovation orientation: The relationship and consequences for innovativeness and performance. Journal of Product Innovation Management, 28(6), 819-832. https://doi.org/10.1111/j.1540-5885.2011.00851.x

Tang, J., Crossan, M., \& Rowe, W. G. (2011). Dominant CEO, deviant strategy, and extreme performance: The moderating role of a powerful board. Journal of Management Studies, 48(7), 1479-1503. https://doi.org/10.1111/j.1467-6486.2010.00985.x

Tellis, G. J., Prabhu, J. C., \& Chandy, R. K. (2009). Radical innovation across nations: The preeminence of corporate culture. Journal of Marketing, 73(1), 3-23. https://doi.org/10.1509/jmkg.73.1.003

Tepper, B. J. (2000). Consequences of abusive supervision. Academy of Management Journal, 43, 178-190. https://doi.org/10.5465/1556375

Walsh, J. P., \& Seward, J. K. (1990). On the efficiency of internal and external corporate control mechanisms. Academy of Management Review, 15(3), 421-458. https://doi.org/10.5465/amr.1990.4308826

Walters, B. A., Kroll, M. J., \& Wright, P. (2007). CEO tenure, boards of directors, and acquisition performance. Journal of Business Research, 60(4), 331-338. https://doi.org/10.1016/j.jbusres.2006.12.001

Wang, H., Tsui, A. S., \& Xin, K. R. (2011). CEO leadership behaviors, organizational performance, and employees' attitudes. The Leadership Quarterly, 22(1), 92-105. https://doi.org/10.1016/j.leaqua.2010.12.009

Weiner, B., Frieze, K., Kukla, A., Reed, L., Rest, S., \& Rosenbaum, R. M. (1972). Perceiving the causes of success and failure. In E. E. Jones, D. E. Kanduse, H. H. Kelley, R. E. Nisbet, S. Valins, \& B. Weiner (Eds.), Attribution: Perceiving the causes of behavior (pp. 95-120). Morristown, NJ: General Learning Press.

Williams, M. J. (2014). Serving the self from the seat of power: Goals and threats predict leaders' self-interested behavior. Journal of Management, 40(5), 1365-1395. https://doi.org/10.1177/0149206314525203

Wrong, D. H. (1968). Some problems in defining social power. American Journal of Sociology, 73(6), 673-681. https://doi.org/10.1086/224561

Zou, T., Ertug, G., \& George, G. (2018). The capacity to innovate: A meta-analysis of absorptive capacity. Innovation, 20(2), 87-121. https://doi.org/10.1080/14479338.2018.1428105

\section{Copyrights}

Copyright for this article is retained by the author(s), with first publication rights granted to the journal.

This is an open-access article distributed under the terms and conditions of the Creative Commons Attribution license (http://creativecommons.org/licenses/by/4.0/). 